\title{
Assessing impacts of climate change to landuse sector in Vinh Long province
}

- Le Ngoc Tuan

University of Science, VNU-HCM

- Nguyen Van Bang

Institute of Meteorology, Hydrology, Oceanology and Environment

Email:Intuan@hcmus.edu.vn

(Received on $29^{\text {th }}$ December 2016, accepted on $17^{\text {th }}$ January 2017)

\section{ASBTRACT}

This work aimed at assessing impacts of climate change $(C C)$ on landuse sector in Vinh Long province to 2020. Flood, saltwater intrusion (SI), drought, landslide, storm, temperature, rainfall were taken into consideration and assessed by data collection, matrix, expert, SWOT, and GIS methods, etc. Results showed that flood and SI were the main factors impacting landuse sector in VinhLong province, especially agricultural land. In all 8 considered districts, in the context of CC, landuse sectors in VungLiem, TraOn, and MangThit districts were of the consideration. Besides, this research indicated strengths, weaknesses, opportunities, and threats of land use sector in the relationship to $C C$ in the local which are important basis for planning suitable adaption measures.

Key words: land use, climate change, saltwater intrusion, flood

\section{INTRODUCTION}

Climate change (CC) is one of the top concerns of nations and tenrritories all over the world. In this context, Vietnam is one of the 5 countries the most affected [1], especially the delta and coastal areas such as the MeKong Delta with the risks of about $39 \%$ acreage flooded in case of $1 \mathrm{~m}$ sea level rise [2]. Therefore, impacts of CC (both positive and negative) need assessing to provide the necessary information to perform plans, projects, monitors, etc. contributing to the improvement of the adaptability of the system.

$\mathrm{CC}$ with manifestations such as temperature increase, precipitation changes, sea level rise, the extreme weather phenomena, etc. heavily impact people and socio-economic sectors where land use is one of sensitive subjects to CC [3, 4], especially to flood and saltwater intrusion (SI). Many different methods have been used to study the relationship between $\mathrm{CC}$ and landuse sector, such as: methods based on historical climate data to assess impacts on landuse sector [5]; linked diagram among $\mathrm{CC}$, disaster management, and landuse planning to propose suitable adaption measures [6]; CLUE model (Conversion of Land Use and Effect) to assess impacts of CC on landuse planning [7-9], Stochastic Climate model to assess impacts of temperature, wind speed, and precipitation on landuse planning [10]; GIS and remote sensing to assess impacts of rainfall, temperature in particular and $\mathrm{CC}$ in general on landuse [11, 12]; place-based model (integrating social, environment, and natural systems) to assess vulnerability [13, 14], etc. Beatley [15] indicated that sustainability, decreasing risks, and the adaptation of community are important factors to balance the relationship between $\mathrm{CC}$ and landuse planning.

Vinh Long province is located in the MeKong Delta where could be the most flooded in the context of sea level rise [2]. The terrain is relatively low as compared to sea level, consequently, the north of the QL1 (Highway 1) is 
usually inundated by flood; area between the QL1 and Mang Thit river is often inundated by both flood and tide; the south of Mang Thit district is mostly flooded by tide. Flooding time is about 2 to 4 months. Besides, SI is also the concern when maximum salinities in main rivers of Vinh Long province have increased over the years (20072016) and increasingly enter the inland (1 \%o salinity boundary). In 2016, higher salinities were recorded in Hau river, Vung Liem, Mang Thit, and Tra On districts (2 \%o salinity boundary); moreover, salinity boundary of $8 \%$ was appeared in Vung Liem district. In addition, natural disasters such as riverbank landslide, storm, drought, etc. have also happened quite frequently, thus seriously impacted lives and production of the local, especially in the context of CC [16].

Therefore, this research aimed at assessing impacts of CC on landuse sector in Vinh Long province to 2020, indicating landuse types needing taking into account according to main impacts of $\mathrm{CC}$, providing basis for planning adaptive measures, contributing to the sustainable development goals of the local.

\section{METHODS}

Impacts of $\mathrm{CC}$ were assessed by related factors such as flood, SI, drought, storm, precipitation, and temperature on landuse sector of Vinh Long province (including Vinh Long city, VungLiem, MangThit, TraOn, TamBinh, BinhTan, BinhMinh, and LongHo districts). Agricultural and non-agricultural land groups were taken into consideration due to a very small acreage of unused land group (about $0.09 \%$ ) [17].

\section{Data collection and processing method}

Data and documents related to landuse, the local CC factors, damages, $\mathrm{CC}$ coping plans of the landuse sector, etc. were collected, then processed by Excel software. Besides, research aimed at assessing impacts of $\mathrm{CC}$ so simulation results of CC scenarios (by SIMCLIM software, according to AR4 record of IPCC [18]), risks of SI and flood due to sea level rise in the context of $\mathrm{CC}$ were inherited. Our previous research showed that in 2020 , according to the average emission scenario (B2), temperature and precipitation in Vinh Long province would be $27.64{ }^{\circ} \mathrm{C}$ and $1,491.80 \mathrm{~mm}$, respectively. For water level, it would increase about $9 \mathrm{~cm}$ as compared to that in the reference period (1980-1999).

\section{Geographic Information System (GIS) method}

The work used Mapinfo 11.5 and ArGIS software to establish maps and calculate impact scope of flood, SI, temperature, and rainfall, etc. on landuse in Vinh Long province to 2020.

\section{CC risk assessment matrix}

This method was used to assess risks due to $\mathrm{CC}$ factors to landuse sector serving determination of concerned areas with respective causes (i.e. the concerned areas and affecting subjects). Depending on occurrence possibility and related damages, risk level due to each CC factor in each local was assessed and classified according to the following scale as presented in Table 1 .

Table 1. Risk level scale due to CC

\begin{tabular}{|c|c|c|c|c|}
\hline $\mathbf{0}<\mathbf{R R} \leq \mathbf{1}$ & $\mathbf{1}<\mathbf{R R} \leq \mathbf{2}$ & $\mathbf{2}<\mathbf{R R} \leq \mathbf{3}$ & $\mathbf{3}<\mathbf{R R} \leq \mathbf{4}$ & $4<\mathbf{R R} \leq \mathbf{5}$ \\
\hline Very low & Low & Average & High & Very high \\
\hline
\end{tabular}

\section{Expert method}

This method was used to determine weights of $\mathrm{CC}$ factors in the relationship to landuse sector based on 20 experts' opinions: (i) Ranking importances of $\mathrm{CC}$ factors to landuse sector (The more important the factor is, the higher the ranking

Trang 226 
score will be); (ii) Determining ranking score of each factor $\left(\mathrm{m}_{\mathrm{i}}\right): m_{i}=$ Total score of factor $i /$ Number of questionaires; (iii) Calculating intermediate weightof each factor $\left(\mathrm{w}_{\mathrm{i}}{ }^{\prime}\right)$ :

\begin{tabular}{l}
\hline Accepting that minimum $\mathrm{m}_{\mathrm{i}}$ \\
has $\mathrm{w}_{\mathrm{i}}{ }^{\prime}=1.0$ \\
\hline+ Calculating $\mathrm{w}_{\mathrm{i}}^{\prime}$ of other factors $\quad w_{i}{ }^{\prime}=\frac{m_{i(\min )}}{m_{i}}$ \\
by formula: \\
+ Calculating final weight of $\mathrm{w}_{i}=\frac{\mathrm{w}_{i}^{\prime}}{\sum_{1}^{n} \mathrm{w}_{i}^{\prime}}$ \\
each factor $\left(\mathrm{w}_{\mathrm{i}}\right)$ :
\end{tabular}

SWOT method (S-Strengths; W-Weaknesses; OOpportunities; T-Threats)

SWOT was used to determine causes and to propose adaption measures to $\mathrm{CC}$ of landuse sector in Vinh Long province: (i) Determine $\mathrm{S}$ and $\mathrm{W}$ of landuse sector in Vinh Long province; (ii) Determine $\mathrm{O}$ and $\mathrm{T}$ of external factors impacting landuse sector in relation to $\mathrm{CC}$; (iii) Analyse and combine logic pairs (S-O, S-T, W-O, W-T), then determine defective chains and propose compatible adaptive measures.

\section{RESULTS AND DISCUSSION}

Current status and landuse planning in Vinh Long province to 2020

Agriculture is a main economic activity, accounting for over $78 \%$ of the natural area [17], contributing more than $33 \%$ of the total economic value of sectors in Vinh Long province [19]. Rice planting activities (LUC) dominates agricultural area mainly distributed in Tam Binh, Vung Liem, and Tra On districts; followed by perennial land (CLN), about 19,200 ha, mostly in Tra On, Long Ho, and Vung Liem districts. For non-agricultural land group, (i) countryside and urban living lands are mainly distributed in Tam Binh and Tra On districts; (ii) dedicated land for other purposes (offices, security, defense, business, public, etc.) are mostly in Long Ho, Mang Thit districts and Vinh Long city, etc. Unused land, about $110 \mathrm{ha}$, accounting for 0.09 $\%$ of the natural area of Vinh Long province. By
2020, in Vinh Long province, there will be $74.08 \%$ of natural area used for agricultural activities and the rest $(25.92 \%)$ for non-agricultural ones [17].

Impact assessment of $\mathrm{CC}$ to land use sector in Vinh Long Province

Agricultural land group

Inundation by tide: Inundation is the factor that most strongly influenced agricultural land types in Vinh Long Province.

Regarding rice, calculations showed about 20.000 ha of rice area (LUC) to be affected by flood, accounting for nearly $28 \%$ of total rice land area in the province. Districts were heavily affected as Vung Liem (6,680.15 ha, 45.16 \%), Long Ho (2,909.09 ha, $42.91 \%$ ), and Tam Binh (2,886.87 ha, $17.23 \%$ ). By 2020 , flooded area could discrease (about 19,850 ha) but flooded rate could increase (accounting for $30.8 \%$ of the rice land area in the province) (Table 2 , Fig.1A). This can be explained by the change in rice landuse planning in 2020 .

Besides, perennial land group (CLN) was also impacted by flood. Calculation showed about 4,543 ha of perennial plant area to be flooded (accounting for $23.64 \%$ ), distributed in Long Ho, Binh Minh, and Tra On districts (Fig.1B). By 2020, flooded perennial plant area could be about 3,544 ha. Similar to rice, because of adjusting landuse planning, flooded perennial plant area could dicrease while flooded rate tends to increase (Table 2).

The province has 1,750 ha of annual crop land (HNK) but 323 ha was flooded (accounting for 18.44\%). Binh Minh district had the largest flooded area. Calculations for 2020 showed flooded annual crop area to be about 378.7 ha, increasing about 56 ha as compared to that in the current status. Binh Minh district needs taking into concern due to about $93 \%$ of annual crop area likely affected by flood (Table 2).

Regarding aquacultural activities (NTS), the province has 1,109 ha for this purpose but $43 \%$ of which was in risk of flood, especially in Long Ho and

Trang 227 
SCIENCE \& TECHNOLOGY DEVELOPMENT JOURNAL:

NATURAL SCIENCE, VOL 1, ISSUE 6, 2017

Tam Binh districts. By 2020, following the increase in aquaculture area in the province (2,052 ha), the area sensitive to flood could expand, including Tra
On, Long Ho, Vung Liem, and Mang Thit districts

(Table 2).

Table 2. Agricultural area (ha) having the risk of flood

\begin{tabular}{|c|c|c|c|c|c|c|c|c|c|c|c|}
\hline Code & Times & & $\begin{array}{l}\text { Binh } \\
\text { Minh }\end{array}$ & $\begin{array}{c}\text { Binh } \\
\text { Tan }\end{array}$ & $\begin{array}{c}\text { Long } \\
\text { Ho }\end{array}$ & $\begin{array}{c}\text { Mang } \\
\text { Thit }\end{array}$ & $\begin{array}{l}\text { Tam } \\
\text { Binh }\end{array}$ & $\begin{array}{c}\text { Vinh } \\
\text { Long city }\end{array}$ & Tra On & $\begin{array}{l}\text { Vung } \\
\text { Liem }\end{array}$ & Total \\
\hline \multirow{4}{*}{ LUC } & \multirow{2}{*}{ Current } & ha & $1,465.6$ & $2,050.4$ & $2,909.1$ & $1,713.1$ & $2,886.9$ & 107.8 & $2,141.2$ & $6,680.2$ & $19,954.3$ \\
\hline & & $\%$ & 37.1 & 21.3 & 42.9 & 24.6 & 17.2 & 23.2 & 17.7 & 45.2 & 28.0 \\
\hline & \multirow{2}{*}{$\begin{array}{c}2020- \\
\text { B2 }\end{array}$} & ha & $1,084.1$ & $1,733.4$ & $2,607.3$ & $1,839.1$ & $2,650.6$ & 26.6 & $2,327.1$ & $7,581.9$ & $19,850.1$ \\
\hline & & $\%$ & 36.3 & 20.7 & 44.9 & 29.8 & 16.7 & 9.1 & 20.3 & 56.0 & 30.8 \\
\hline \multirow{4}{*}{ CLN } & \multirow{2}{*}{ Current } & ha & 879.6 & 115.4 & 957.6 & 404.2 & 288.0 & 577.5 & 674.4 & 646.4 & $4,543.0$ \\
\hline & & $\%$ & 55.6 & 11.4 & 26.8 & 19.8 & 13.4 & 46.7 & 15.2 & 20.2 & 23.6 \\
\hline & \multirow{2}{*}{$\begin{array}{c}2020- \\
\text { B2 }\end{array}$} & ha & 579.3 & 76.5 & 970.0 & 457.2 & 245.7 & 4.8 & 532.2 & 678.0 & $3,543.7$ \\
\hline & & $\%$ & 58.6 & 11.0 & 33.1 & 28.4 & 13.8 & 12.8 & 15.4 & 25.8 & 25.1 \\
\hline \multirow{4}{*}{ NTS } & \multirow{2}{*}{ Current } & ha & 19.3 & 6.5 & 168.2 & 63.7 & 102.3 & 22.7 & 39.1 & 56.2 & 477.9 \\
\hline & & $\%$ & 59.8 & 4.6 & 51.4 & 49.0 & 56.4 & 67.9 & 41.3 & 32.9 & 43.1 \\
\hline & \multirow{2}{*}{$\begin{array}{c}2020- \\
\text { B2 }\end{array}$} & ha & 56.5 & - & 198.4 & 139.1 & 35.2 & - & 417.7 & 174.2 & $1,021.2$ \\
\hline & & $\%$ & 82.3 & - & 71.4 & 72.0 & 34.9 & - & 76.1 & 30.9 & 49.8 \\
\hline \multirow{4}{*}{ HNK } & \multirow{2}{*}{ Current } & ha & 156.5 & 23.5 & 34.0 & 20.0 & 30.0 & 6.9 & 23.1 & 28.9 & 322.8 \\
\hline & & $\%$ & 65.1 & 5.1 & 36.0 & 30.8 & 11.1 & 22.8 & 8.4 & 9.0 & 18.4 \\
\hline & \multirow{2}{*}{$\begin{array}{c}2020- \\
\text { B2 }\end{array}$} & ha & 203.2 & 34.6 & 46.6 & 85.9 & 8.3 & - & - & - & 378.7 \\
\hline & & $\%$ & 93.0 & 9.5 & 36.7 & 80.1 & 18.5 & - & - & - & 40.4 \\
\hline \multirow{4}{*}{ Total } & \multirow{2}{*}{ Current } & ha & $2,521.0$ & $2,195.8$ & $4,068.9$ & $2,200.9$ & $3,307.2$ & 714.9 & $2,877.8$ & $7,411.6$ & $25,298.0$ \\
\hline & & $\%$ & 43.5 & 19.6 & 37.8 & 23.9 & 17.1 & 40.5 & 17.0 & 40.1 & 27.1 \\
\hline & \multirow{2}{*}{$\begin{array}{c}2020- \\
\text { B2 }\end{array}$} & ha & $1,923.2$ & $1,844.5$ & $3,822.4$ & $2,521.2$ & $2,939.8$ & 31.4 & $3,277.0$ & $8,434.2$ & $24,793.7$ \\
\hline & & $\%$ & 45.1 & 18.9 & 41.8 & 31.2 & 16.5 & 9.5 & 21.1 & 50.4 & 30.4 \\
\hline
\end{tabular}

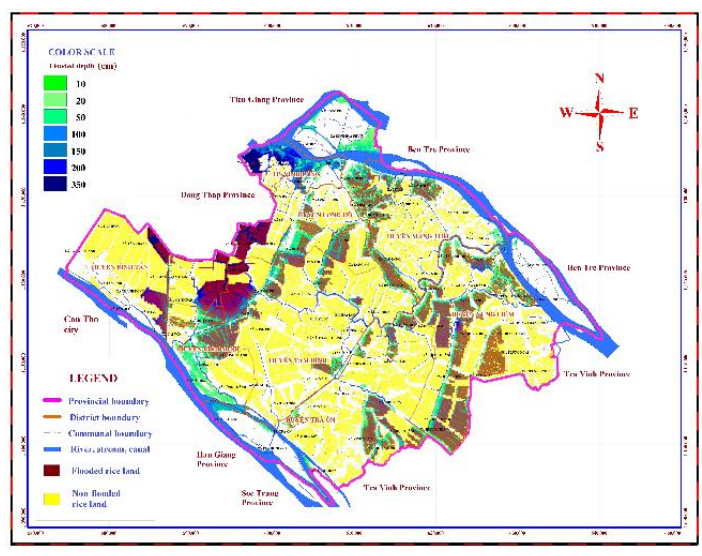

(A)

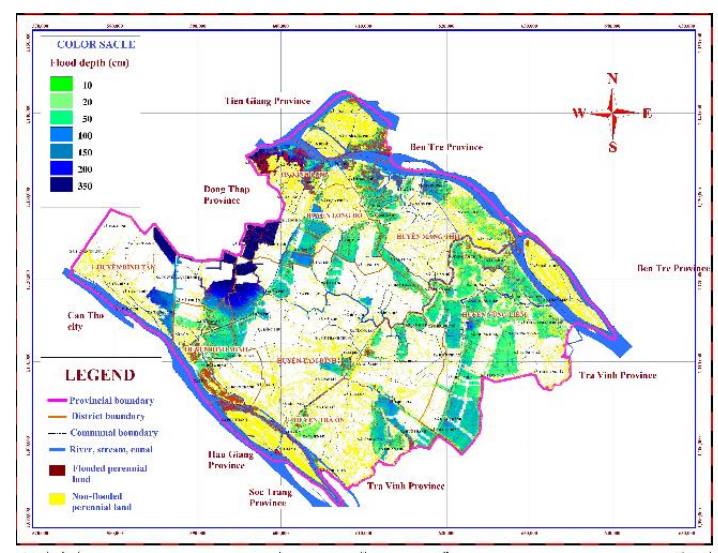

(B)

Fig. 1. Maps of current status of inundation in Vinh Long province: (A) rice land; (B) perennial plant land - SI and drought

\section{Trang 228}


TẠP CHÍ PHÁT TRIỂN KHOA HỌC \& CÔNG NGHỆ: CHUYÊN SAN KHOA HỌC TỤ’ NHIÊN, TậP 1, SỐ 6, 2017

Table 3. Agricultural area (ha) having the risk of SI in Vinh Long province

\begin{tabular}{|c|c|c|c|c|c|c|c|c|c|c|}
\hline \multirow{2}{*}{ Code } & \multirow{2}{*}{ Times } & & \multicolumn{2}{|c|}{ Mang Thit } & \multicolumn{2}{|c|}{ Tra On } & \multicolumn{2}{|c|}{ Vung Liem } & \multicolumn{2}{|c|}{ Total } \\
\hline & & & $1 \%$ & $4 \%$ & $1 \% 0$ & $4 \%$ & $1 \% 0$ & $4 \%$ & $1 \% 0$ & $4 \% 0$ \\
\hline \multirow{4}{*}{ LUC } & \multirow{2}{*}{ Current } & ha & 582.64 & 0 & $1,036.15$ & 0 & $13,016.78$ & 767.28 & $14,635.57$ & 767.28 \\
\hline & & $\%$ & 8.38 & & 8.56 & & 88.01 & 5.19 & 20.50 & 1.07 \\
\hline & \multirow{2}{*}{$2020-\mathrm{B} 2$} & ha & 991.33 & 0 & $2,475.29$ & 0 & $12,915.94$ & $2,032.32$ & $16,382.56$ & $2,032.32$ \\
\hline & & $\%$ & 16.09 & & 21.61 & & 95.48 & 15.02 & 25.41 & 3.15 \\
\hline \multirow{4}{*}{ CLN } & \multirow{2}{*}{ Current } & ha & 625.74 & 0 & 144.99 & 0 & $2,873.62$ & 257.42 & $3,644.35$ & 257.42 \\
\hline & & $\%$ & 30.59 & & 3.28 & & 89.78 & 8.04 & 18.96 & 1.34 \\
\hline & \multirow{2}{*}{$2020-\mathrm{B} 2$} & ha & 827.71 & 0 & 403.29 & 0 & $2,508.01$ & 834.37 & $3,739.01$ & 834.37 \\
\hline & & $\%$ & 51.39 & & 11.64 & & 95.53 & 31.78 & 26.44 & 5.90 \\
\hline \multirow{4}{*}{ NTS } & \multirow{2}{*}{ Current } & ha & 35.74 & 0 & 0.90 & 0 & 171.42 & 21.86 & 208.06 & 21.86 \\
\hline & & $\%$ & 27.51 & & 0.94 & & 95.7 & 12.21 & 18.76 & 1.97 \\
\hline & \multirow{2}{*}{$2020-\mathrm{B} 2$} & ha & 112.34 & 0 & 15.06 & 0 & 571.42 & 258.84 & 698.81 & 258.84 \\
\hline & & $\%$ & 58.13 & & 2.74 & & 98.88 & 44.79 & 34.05 & 12.61 \\
\hline \multirow{4}{*}{ HNK } & \multirow{2}{*}{ Current } & ha & 6.02 & 0 & 3.89 & 0 & 275.69 & 83.74 & 285.60 & 83.74 \\
\hline & & $\%$ & 9.29 & & 1.43 & & 86.03 & 26.13 & 16.31 & 4.78 \\
\hline & \multirow{2}{*}{$2020-\mathrm{B} 2$} & ha & 0 & 0 & 0 & 0 & 0 & 0 & 0 & 0 \\
\hline & & $\%$ & & & & & & & & \\
\hline \multirow{4}{*}{ Total } & \multirow{2}{*}{ Current } & ha & $1,250.15$ & 0 & $1,185.92$ & 0 & $16,337.50$ & $1,130.9$ & $18,773.57$ & $1,130.29$ \\
\hline & & $\%$ & 13.60 & & 7.02 & & 88.39 & 6.12 & 20.08 & 1.21 \\
\hline & \multirow{2}{*}{$2020-\mathrm{B} 2$} & ha & $1,931.37$ & 0 & $2,893.64$ & 0 & $15,995.37$ & $3,125.54$ & $20,820.38$ & $3,125.54$ \\
\hline & & $\%$ & 23.93 & & 18.64 & & 95.60 & 18.68 & 25.52 & 3.83 \\
\hline
\end{tabular}

In all landuse types in Vinh Long province, agriculcutal landuse is the most sensitive to SI, especially in Vung Liem (0.5-4 \%o), Mang Thit (0.5-1 \%o), and Tra On districts (0.5-1 \%o). Calculated results showed about 18,700 ha $(20.08$ $\%$ of total agriculcutal area in the province) and about 1,130 ha of agriculcutal area $(1.21 \%)$ to be in $1 \%$ and $4 \%$ salty areas, respectively (Table 3).According to medium emission scenario (B2 scenario), SI tends to expand in southern area of Tra On district and northern area of Mang Thit district, nearby Hau river and Co Chien river.

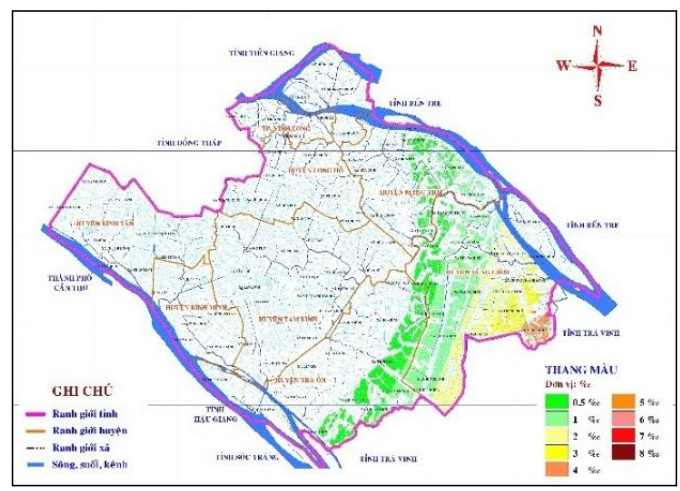

(A)
Vung Liem district could be mostly affected because most agricultural area was in $1 \%$ salty area (Table 3), in which, a part of Trung Nghia, Trung Ngai, Trung Thanh Dong, and Quoi Thien communes were affected by salinity of $4 \%$ (Fig. 2 and 3 ).

In all landuse types, rice and perennial plant land areas were significantly affected by SI, especially Vung Liem, Mang Thit, and Tra On districts. Notably, by 2020, the area affected by SI could expand larger than that in the current status.

Fig. 2. Rice land having risk of SI in Vinh Long province: (A) Current status, (B) 2020 - B2 Scenario

Trang 229 
Beside SI, drought is also the factor exacerbating impacts of SI. Drought often occurs in high areas not taking advantages of gravity irrigation and semi-gravity irrigation, leading to the propagation of salinity to inland, and then

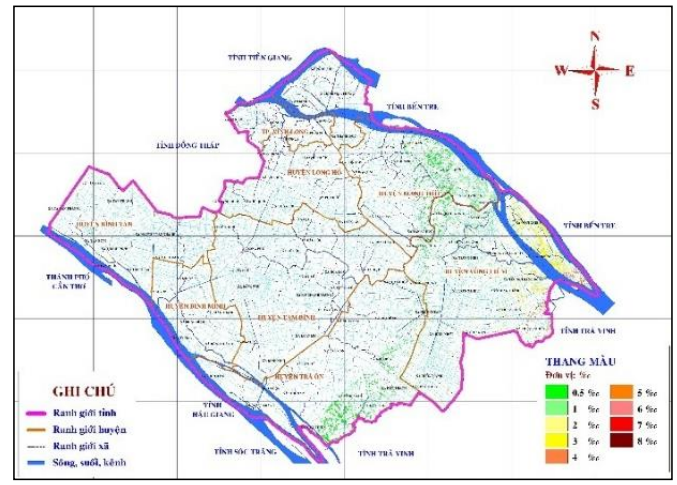

(A)

Fig. 3. Perennial plant land having risk of SI:

\section{- Other phenomena}

Riverbank landslide often occurs in soft ground areas nearby riverbank and mostly affects irrigation works, houses, traffic, etc. For agricultural landuse sector, landslide insignificantly affects. Temperature, rainfall, and storm in Vinh Long province also resulted in similar statements.

To sum up, flood and SI are 2 main factors affecting agricultural land group of Vinh Long province, especially the rice land. This work also indicated agricultural landuse sector in Vung Liem (due to flood, SI), Long Ho (due to flood), Tam Binh (due to flood), and Tra On (due to SI) districts need taking into the consideration. By 2020 , in the context of CC increasingly serious, agricultural landuse sector in Vinh Long province also face to more risks. affect the growth of rice as well as domestic water supply. In 2016, drought harmed 1,884 ha of crop in Vung Liem district, corresponding to 16 billion VND [19].

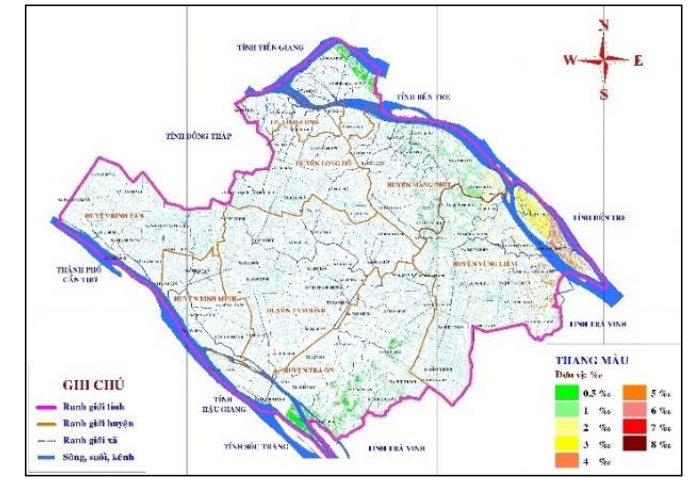

(B)

(A) Current status, (B) 2020 - B2 Scenario

Non-agricultural land groups

- $\quad$ Inundation by tide

Calculated results showed about 9,146.65 ha of non-agricultural land area to be inundated (25\% of total non-agricultural land area). Long Ho, Vung Liem, Tam Binh districts, and Vinh Long city need taking into the consideration due to more than 1,000 ha of non-agricultural land area inundated in each local. By 2020, the risk of flood could be 2 times as many as that in the current (up to $17,411.67 \mathrm{ha}$ ) due to impacts of sea level rise as well as the increase in total area of nonagricultural land (over 50,000 ha) according to landuse planning. Long Ho, Vung Liem districts and Vinh Long city could be still sensitive areas to flood and CC (Table 4).

Table 4. Area (ha) of non-agricultural having the risk of flood in Vinh Long Province

\begin{tabular}{|c|c|c|c|c|c|c|c|c|c|c|c|}
\hline Code & & & Binh Minh & Binh Tan & Long Ho & $\begin{array}{c}\text { Mang } \\
\text { Thit }\end{array}$ & Tam Binh & $\begin{array}{l}\text { Vinh } \\
\text { Long }\end{array}$ & Tra On & $\begin{array}{l}\text { Vung } \\
\text { Liem }\end{array}$ & Total \\
\hline \multirow{3}{*}{ OTC } & \multirow{2}{*}{ Current } & ha & 774.1 & 423.6 & $1,412.8$ & 724.8 & $1,045.6$ & 785.9 & 938.4 & $\begin{array}{l}1,668.8 \\
\end{array}$ & 7,774 \\
\hline & & $\%$ & 41.0 & 18.6 & 29.3 & 21.5 & 16.4 & 53.4 & 15.3 & 23.7 & 23.3 \\
\hline & $2020-2$ nd & ha & $1,296.3$ & 640.4 & $2,415.8$ & $1,211.2$ & $1,381.7$ & $1,405.8$ & $1,479.0$ & $2,927.5$ & $12,757.7$ \\
\hline
\end{tabular}

Trang 230 
TẠP CHÍ PHÁT TRIỂN KHOA HỌC \& CÔNG NGHẸ: CHUYÊN SAN KHOA HỌC TỬ NHIÊN, TẬP 1, SỐ 6, 2017

\begin{tabular}{|c|c|c|c|c|c|c|c|c|c|c|c|}
\hline & & $\%$ & 50.5 & 20.8 & 41.6 & 29.2 & 18.8 & 61.2 & 20.6 & 35.4 & 31.4 \\
\hline \multirow{4}{*}{$\mathrm{CDG}$} & \multirow{2}{*}{ Current } & ha & 143.0 & 118.0 & 389.1 & 131.0 & 99.7 & 282.8 & 16.5 & 41.1 & $1,221.2$ \\
\hline & & $\%$ & 64.3 & 65.7 & 61.4 & 27.8 & 47.7 & 92.2 & 14.6 & 32.4 & 54.0 \\
\hline & \multirow{2}{*}{$2020-2$ nd } & ha & 522.5 & 545.1 & $1,001.6$ & 470 & 359.3 & 867.4 & 333.2 & 365.4 & $4,464.5$ \\
\hline & & $\%$ & 43.1 & 45.9 & 57.6 & 45.2 & 32.5 & 68.2 & 32.0 & 42.3 & 47.2 \\
\hline \multirow{4}{*}{ NTD } & \multirow{2}{*}{ Current } & ha & 7.0 & 1.7 & 23.6 & 17.8 & 9.3 & 27.5 & 14.2 & 50.4 & 151.4 \\
\hline & & $\%$ & 34.2 & 9.6 & 32.3 & 19.7 & 20.0 & 64 & 11.5 & 29.1 & 25.8 \\
\hline & \multirow{2}{*}{$2020-2$ nd } & ha & 7.8 & 1.3 & 30.6 & 25.1 & 17.6 & 22.9 & 20 & 64.1 & 189.4 \\
\hline & & $\%$ & 39.2 & 7.4 & 41.1 & 31.2 & 29.6 & 53.5 & 17.1 & 36.4 & 32,2 \\
\hline \multirow{4}{*}{ Total } & \multirow{2}{*}{ Current } & ha & 924.2 & 543.4 & $1,825.4$ & 873.6 & $1,154.6$ & $1,096.2$ & 969.0 & $1,760.2$ & $9,146.6$ \\
\hline & & $\%$ & 43.3 & 21.9 & 33.0 & 22.2 & 17.4 & 60.2 & 15.2 & 24 & 25.2 \\
\hline & \multirow{2}{*}{$2020-2$ nd } & ha & $1,826.6$ & $1,186.7$ & $3,448.1$ & $1,706.3$ & $1,758.6$ & $2,296.1$ & $1,832.2$ & $3,357.1$ & $17,411.7$ \\
\hline & & $\%$ & 48.1 & 27.7 & 45.3 & 32.4 & 20.7 & 63.6 & 22.0 & 36.0 & 34.3 \\
\hline
\end{tabular}

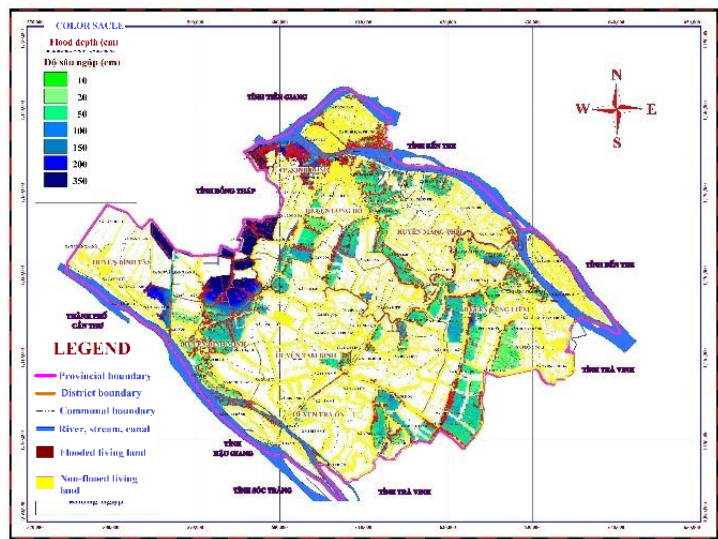

(A)

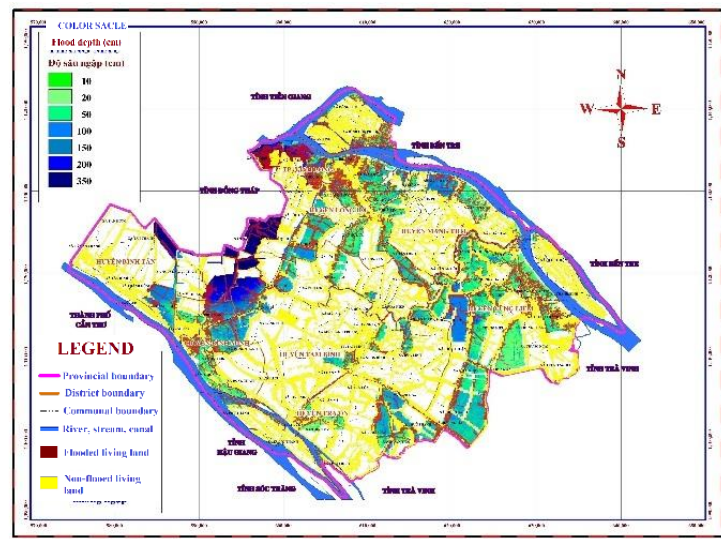

(B)

Fig. 4. Land having risk of flood in Vinh Long province: (A) Current status, (B) 2020 - Scenario

According to Table 4, while graveyard land is only 587 ha $(1.6 \%)$ and insignificantly changes to 2020, living land and dedicated land are 2 main types of non-agricultural land with $33,419.97$ ha (92\%) and 2,261.2 ha (6\%), respectively, therefore, the latter two types were taken into the consideration in this work.

Living land: total flooded area was about 7,774 ha (23\% of province area). By 2020, flooded rate tends to increase. With specific characteristics of urban area, Vinh Long city and Binh Minh town had the highest rate of flooded area corresponding to $41 \%$ and $53.4 \%$. These figures could be $50.5 \%$ and $61.2 \%$, respectively in 2020 (Table 4 - Fig. 4).

Dedicated land: calculated results showed more than 1,200 ha ( $54 \%$ ) of dedicated land could be flooded currently; distributed in Vinh Long city (282 ha, accounting for $92 \%$ ), the highest flooded rate of dedicated land, followed by Binh Tan, Binh Minh, and Long Ho districts corresponding 118 ha (65.7\%), 143 ha (64.25\%), and 389 ha $(61.4 \%)$, respectively (Table 4). By 2020, the flooded dedicated land area in the whole province could increase as 4 times many as that in the current status, about 4,464 ha, noted in Long Ho, Vinh Long city, and Binh Tan. It could be explained by impacts of sea level rise in the context of $\mathrm{CC}$ as well as the expansion of dedicated land area in the future $(9,461.77$ ha, as 4 times more than as that in the current status).

\section{- Riverbank landslide}

Riverbank landslide often occurs in the province, especially in Tra On, Vinh Long City,

Trang 231 
SCIENCE \& TECHNOLOGY DEVELOPMENT JOURNAL:

NATURAL SCIENCE, VOL 1, ISSUE 6, 2017

Vung Liem, and Long Ho districts. In 2014, there were 6 landslide positions in the inland and along main rivers in Mang Thit, Long Ho districts and Vinh Long city, destroyed about $250 \mathrm{~m}$ of riverbank, dikes, and roads, etc. In 2015, there were 39 landslide positions extraordinarily occuring (excepting the landslide positions at construction sites), resulting in damages to property, houses, crops as well as the human's life [21]. In genreal, landslide affects infrastructures in Vung Liem, Long Ho, Tra On, and Mang Thit districts, especially in Vinh Long city.

\section{- $\quad$ Other phenomena}

Drought: in recent years, droughts have widely occurred at the end of April. Vung Liem, Binh Tan, Tam Binh, and a part of Binh Minh districts (Dong Thanh commune) are needed to be yaken into the consideration. However, drought as well as SI insignificantly affect non-agricultural landuse in the province while rainfall and storm mostly affect infrastructures and people.

Similar to agricultural land group, flood is the top concern of non-agricultural land group in Vinh Long province. Besides, riverbank landslide also causes certain impacts. Accordingly, nonagricultural landuse sector in Long Ho, Vung Liem, Tam Binh districts and Vinh Long city need concerning in the context of CC.

\section{Determination of concerned $\mathrm{CC}$ factors and hotspot areas}

Based on the impact level and possibility of appearance of $\mathrm{CC}$ factors, the $\mathrm{CC}$ risk assessment matrix for landuse sector in Vinh Long province was presented in Table 5.

Table 5. The CC risk assessment for landuse sector in Vinh Long province (*: weight)

\begin{tabular}{|c|c|c|c|c|c|c|c|c|c|c|}
\hline \multirow{2}{*}{$\begin{array}{l}\text { District/ } \\
\text { city }\end{array}$} & & \multirow{2}{*}{$\begin{array}{c}\text { SI } \\
0.19 *\end{array}$} & \multirow{2}{*}{$\begin{array}{c}\text { Flood } \\
0.23 \\
\end{array}$} & \multirow{2}{*}{$\begin{array}{c}\begin{array}{c}\text { Land- } \\
\text { slide }\end{array} \\
0.18 \\
\end{array}$} & \multirow{2}{*}{$\begin{array}{c}\text { Drought } \\
0.12 \\
\end{array}$} & \multirow{2}{*}{$\begin{array}{c}\text { Temper- } \\
\text { ature }\end{array}$} & \multirow{2}{*}{$\begin{array}{c}\begin{array}{c}\text { Rain- } \\
\text { fall }\end{array} \\
0.1 \\
\end{array}$} & \multirow{2}{*}{$\begin{array}{c}\text { Storm } \\
0.07 \\
\end{array}$} & \multicolumn{2}{|c|}{ Total } \\
\hline & & & & & & & & & Average & Max \\
\hline \multirow{2}{*}{$\begin{array}{l}\text { Binh } \\
\text { Minh }\end{array}$} & Current & 0 & 2 & 1 & 1 & 0 & 0 & 0 & 0.76 & 2 \\
\hline & 2020 & 0 & 3 & 1 & 1 & 0 & 0 & 0 & 0.99 & 3 \\
\hline \multirow{2}{*}{ Binh Tan } & Current & 0 & 1 & 0 & 0 & 0 & 0 & 0 & 0.23 & 1 \\
\hline & 2020 & 0 & 2 & 0 & 0 & 0 & 0 & 0 & 0.46 & 2 \\
\hline \multirow{2}{*}{ Long Ho } & Current & 0 & 4 & 0 & 0 & 0 & 0 & 0 & 0.92 & 4 \\
\hline & 2020 & 1 & 4 & 1 & 0 & 0 & 0 & 0 & 1.29 & 4 \\
\hline \multirow{2}{*}{$\begin{array}{l}\text { Mang } \\
\text { Thit }\end{array}$} & Current & 3 & 2 & 1 & 0 & 0 & 0 & 0 & 1.21 & 3 \\
\hline & 2020 & 4 & 3 & 0 & 0 & 0 & 0 & 0 & 1.45 & 4 \\
\hline \multirow{2}{*}{ Tam Binh } & Current & 0 & 4 & 0 & 1 & 0 & 0 & 0 & 1.04 & 4 \\
\hline & 2020 & 1 & 4 & 0 & 1 & 0 & 0 & 0 & 1.23 & 4 \\
\hline \multirow{2}{*}{$\begin{array}{c}\text { Vinh } \\
\text { Long city }\end{array}$} & Current & 0 & 2 & 2 & 0 & 0 & 0 & 0 & 0.82 & 2 \\
\hline & 2020 & 0 & 3 & 2 & 0 & 0 & 0 & 0 & 1.05 & 3 \\
\hline \multirow{2}{*}{ Tra On } & Current & 3 & 3 & 2 & 0 & 0 & 0 & 0 & 1.62 & 3 \\
\hline & 2020 & 4 & 4 & 2 & 0 & 0 & 0 & 0 & 2.04 & 4 \\
\hline \multirow{2}{*}{$\begin{array}{l}\text { Vung } \\
\text { Liem } \\
\end{array}$} & Current & 4 & 4 & 1 & 3 & 0 & 0 & 0 & 2.22 & 4 \\
\hline & 2020 & 5 & 5 & 1 & 3 & 0 & 0 & 0 & 2.64 & 5 \\
\hline \multirow{2}{*}{ Total } & Current & 10 & 22 & 7 & 5 & 0 & 0 & 0 & & \\
\hline & 2020 & 15 & 28 & 7 & 5 & $\mathbf{0}$ & $\mathbf{0}$ & $\mathbf{0}$ & & \\
\hline
\end{tabular}

Table 5 indicated the flood and SI, main factors increasing risk for landuse sector of Vinh Long province, especially flood due to its wide scope and high level of impacts. The areas are needed to be taken into the consideration in the relationship between landuse sector and CC factors include Vung Liem, Tra On, and Mang Thit districts (due to flood and SI), Vinh Long city and Binh Minh town (due to flood) (Fig. 5).

\section{Trang 232}


TẠP CHÍ PHÁT TRIỂN KHOA HỌC \& CÔNG NGHỆ: CHUYÊN SAN KHOA HỌC TỰ NHIÊN, TậP 1, SỐ 6, 2017

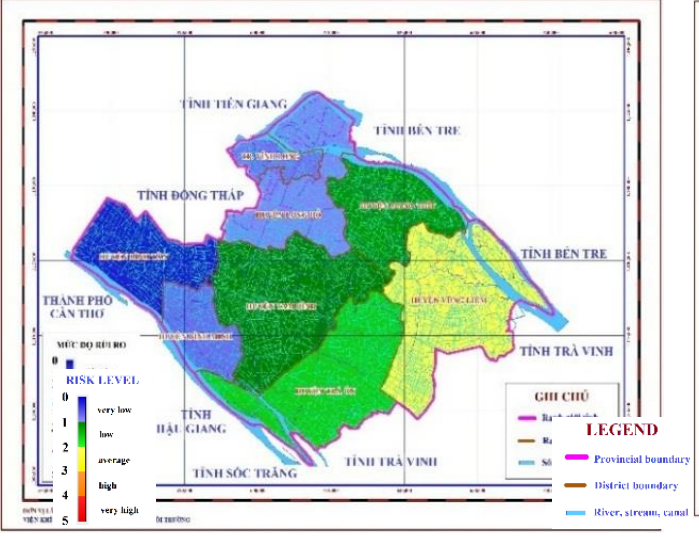

(A)

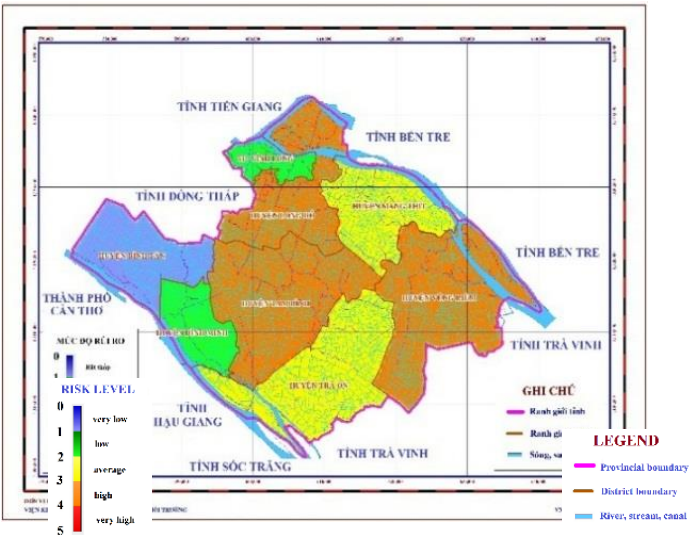

(B)

Fig. 5. Current status of risk index due to $\mathrm{CC}$ of landuse sector in Vinh Long Province: (A) Average; (B) Maximum

Opportunities and Threats of land use sector in Vinh Long province in the context of CC

Table 6 recapitulated of strenghts, weaknesses, opportunities, and threats of landuse sector in Vinh Long province in the context of CC.

Table 6. Strenghts, weaknesses, opportunities, and threats of landuse sector in Vinh Long province in the context of $\mathrm{CC}$

\begin{tabular}{|c|c|}
\hline Strenght (S) & Weakness (W) \\
\hline $\begin{array}{l}\text { - S1: Relative flat terrain; inning from Tien river and Hau } \\
\text { river; relative good soil quality (balances nutritional } \\
\text { ingredients) [16]. } \\
\text { - S2: Located in the center of Mekong delta; thriving } \\
\text { agriculture sector; ensurement of local food security. } \\
\text { - S3: Medium adaptive capability to CC of the community } \\
\text { and local authorities [20]. } \\
\text { - S4: Being particularly interested planning and orientation } \\
\text { of exploiting and developing landuse sector to } 2020 \text {, vision } \\
\text { to } 2030 \text { [16]. } \\
\text { - S5: Investment of irrigation system and dikes to prevent } \\
\text { flood, riverbank landslide, etc [20]. }\end{array}$ & $\begin{array}{l}\text { - W1: Hollow terrain and relative low (high risk of tidal } \\
\text { flooding). } \\
\text { - W2: Limited experience of response to CC of community } \\
\text { in some locals [20]. } \\
\text { - W3:Limited capability of accessing CC information of } \\
\text { community [20]. } \\
\text { - W4: Lack of adequate attention of responding to climate } \\
\text { change in a number of state authorities [20]. } \\
\text { - W5: Low effectiveness in implementation of CC coping } \\
\text { plan in some locals (i.e. discrete, not focus) [20]. } \\
\text { - W6: Complex river system; Being affected by semi-diurnal } \\
\text { tide (risk of SI) }\end{array}$ \\
\hline Opportunities (O) & Threats (T) \\
\hline $\begin{array}{l}\text { - O1: Advantages for agricultural sector due to an increase in } \\
\text { temperature and prolonged dry season (to dry agricultural } \\
\text { products, etc) } \\
\text { - O2: Opportunities to mobilize finance to cope with CC and } \\
\text { disasters from government, local authorities, and } \\
\text { international sources (AFD, New Zealand partnerships for } \\
\text { International Development Fund, etc), [22] } \\
\text { - O3: Ease of spreading CC information on different media } \\
\text { (Tv, internet, newspaper, etc.) }\end{array}$ & $\begin{array}{l}\text { - T1: Occurrence of flooding almost over the province; } \\
\text { tendency to increase to } 2020 \text {. } \\
\text { - T2: SI in Vung Liem, Tra On, and Mang Thit districts; } \\
\text { tendency to increasingly propagate to the inland } \\
\text { - T3: Risks of droughts combining to tides }\end{array}$ \\
\hline
\end{tabular}

Accordingly, relationships among $\mathrm{S}, \mathrm{W}, \mathrm{O}$, and $\mathrm{T}$ were as follows: (i) $\mathrm{S} 1+\mathrm{O} 2$ : Increasing investment (both internal and external of the province) to improve

Trang 233 
agricultural land quality and ensure the food security.

(ii) $\mathrm{S} 2+$ O1: Taking advantages of temperature increase to diversify ways of processing agricultural products and to save energy.

(iii) S3 + O3: Improving the respond capacity to $\mathrm{CC}$ of community and local authorities by assistant programs, finance sources from government and local authorities as well as international organizations.

(iv) $\mathrm{O} 3-\mathrm{W} 3$ : Increasing the response capability to $\mathrm{CC}$ by increasing communication programs.

(v) O2 - W1, W6: Taking advantages of funding and financial supports; studying and constructing suitable tidal dyke system as well as, minimize SI.

(vi) S3 - T1, T2, T3: Promoting the strengths of coping capacity of community in the context of increasingly serious $\mathrm{CC}$.

(vii) S4 - T1, T2: Studying and suitable allocating land resource to ensure the socioeconomic development as well as to minimize CC damages.

(viii) S5 - T1: Taking into account effects of flooding in designing and constructing irrigation system in the local.

(ix) T2 - W1: Setting up pump stations, irrgation dikes, etc. to minimize $\mathrm{CC}$ impacts on low terrain and hollow areas in the local. (x) T1, T2 - W5: Planning the CC response programs, especially response to flooding and SI for landuse sector.

To sum up, solutions contributing to improve the respond capacity to $\mathrm{CC}$ of landuse sector in Vinh Long province including: adaptive measures (iii, v, vii, ix, x), mitigative measures (ii) and assistant measures (i, iv, vi, viii), matching the Support Programme to respond to climate change in Vietnam [23].

\section{CONCLUSION}

The research aimed at assessing impacts of $\mathrm{CC}$ on landuse sector in Vinh Long province to 2020. Regarding the agricultural land group (the most affected group), flooding and SI were 2 main factors impacting most seriously, especically in Vung Liem (flooding, SI), Tra On (flooding), and Mang Thit (flooding) districts. Droughts partly impacted Vung Liem district while rainfall, temperature, and storm insignificantly affected. Regarding non-agricultural land group, flooding and riverbank landslide need the attention, especically in Vinh Long city (flooding, landslide), Binh Minh town (flooding), and Tra On district (landslide). SI, temperature, rainfall, and storm, etc. had little impacts on this landuse type. Besides, this work analyzed strengths, weaknesses, opportunities, and threats of landuse sector in Vinh Long province. Measurementthe adaptive capacity to $\mathrm{CC}$ was then suggested, contributing to increase the $\mathrm{CC}$ response efficiency in the local. 


\section{Đánh giá tác động của biến đổi khí hậu đến lĩnh vực sử dụng đất tỉnh Vĩnh Long}

- Lê Ngọc Tuấn

Trường Đại học Khoa học Tự nhiên, ĐHQG-HCM

- Nguyễn Văn Bằng

Viện Khí tượng Thủy văn Hải văn và Môi trường

\section{TÓM TẮT}

Nghiên cưu nhằm muc tiêu đánh giá tác động của biến đổi khí hậu (BĐKH) đến lĩnh vực sủ dụng đất (SDĐ) tỉnh Vĩnh Long đến năm 2020. Các yếu tố được xem xét, đánh giá bao gồm ngập, xâm nhập mặn (XNM), hạn hán, sạt lở, giông lốc, nhiệt độ và lượng mưa thông qua các phưong pháp tổng hơp tài liệu, ma trận đánh giá, phuoong pháp chuyên gia, phân tích SWOT, GIS.... Kết quả cho thấy ngập và XNM tác động nhiều nhất đến lĩnh vục SDĐ tỉnh Vĩnh Long, đặc biệt là loại hình đất nông nghiệp. Trong tất cả 8 huyện thị được xét, trước nhũng diễn biến bất lợi của $B Đ K H$, các địa phuoong có lĩnh vục SDĐ đáng quan tâm bao gồm huyện Vũng Liêm, Trà Ôn và Mang Thít. Bên cạnh đó, nghiên cứu cũng chỉ ra các thế mạn, điểm yếu, co hội và thách thức của lĩnh vực SDĐ trong mối quan hệ với BĐKH tại địa phuoonglàm cơ sỏ quan trọng để hoạch định các giải pháp thích ưng twong thich.

Tù khóa: sủ dụng đất, biến đổi khỉ hậu, xâm nhập mặn, ngập lụt

\section{REFERENCES}

[1]. World Bank. 2007. World Development Report.

[2]. Bộ Tài nguyên và Môi trường. 2012. Kịch bản Biến đổi khí hậu và nước biển dâng cho Việt Nam.

[3]. Mendelsohn, Robert, The Impact of Climate Change on Land. Climate Change and Land Policies, eds. Ingram, Gregory K. and $\mathrm{Yu}$ Hung Hong. Cambridge, MA: Lincoln Institute of Land Policy, 62-83 (2011).

[4]. North East Climate Science Center NECSC, Climate impacts on land-use and land-cover change (2016). https://necsc.umass.edu/content/climateimpacts-land-use-and-land-cover-change

[5]. A. Campbell, Climate change adaptation in the Metropolitan Washington Region: Draft Transportation Sector Vulnerabilities. Metropolitan Washington Council of Governments (MWCOG, COG (2011).

[6]. Bajracharya at el., Climate change adaptation through land use planning and disaster management: Local government perspectives from Queensland. 17th Pacific Rim Real Estate Society Conference: Climate change and property: Its impact now and later. 16-19/1/2011, Gold Coast (2011).

[7]. M.H.V.Meijl, T.van Rheenen, A.Tabeau, B.Eickhout, The impact of different policy environments on agricultural land use in Europe,Agr. Ecosyst. Environ, 114, 21-38 (2006).

[8]. P.H.Verburg, B.Eickhout, H.van Meijl, A multi-scale, multi-model approach for analyzing the future dynamics of European land use, The Annals of Regional Science, 42, 57-77 (2008).

[9]. M. van Dijk, M. Rutten, W. van Rooij, H. Hilderink, Land Use Dynamics, Climate change, and food security in Vietnam: A global-to-local modeling approach,World Development, 59, 29-46 (2014). 
[10]. Parks at el. 2007. Climate change impacts and adaptations for land use planner. Birch Hill GeoSolutions.

[11]. T.D. Mitchell, P.D. Jones, An improved method of constructing a database of monthly climate observations and associated high-resolution grids, Int. J. Climatol., 25: 693-712 (2005).

[12]. H.Hossain, C.Evans, V.Sposito, Sustainable land resource assessment in regional and urban systems'. Applied GIS Volume 2, Number 3. Monash University Epress, 24.124.21 (2006).

[13]. S.L Cutter, Vulnerability to environmental hazards, Progress in Human Geography, 20, 529-539 (1996).

[14]. S.L. Cutter, L. Barnes, M. Berry, C. Burton, E. Avans, E. Tate, J. Webb, A place-based model for understanding community resilience to natural disasters, Global Environmental Change, 18, 4, 598-606 (2008).

[15]. T. Beatley, Planning for Coastal Resilience: Best Practices for Calamitous Times. London, Island Press (2009).
[16]. UBND tỉnh Vĩnh Long, Báo cáo hiện trạng môi trường tỉnh Vĩnh Long giai đoạn 2010 2015 (2015).

[17]. UBND tỉnh Vĩnh Long, Báo cáo thuyết minh Quy hoạch sử dụng đất tỉnh Vĩnh Long đến năm 2020 và kế hoạch sử dụng đất 5 năm kỳ đầu 2011-2015.

[18]. IPCC, Climate Change 2007: Synthesis Report (IPCC Forth Assessment Report AR4) (2007).

[19]. Cục Thống kê tỉnh Vĩnh Long, 2016. Niên giám thống kê tỉnh Vĩnh Long 2015.

[20]. UBND tỉnh Vĩnh Long, 2016. Báo cáo tổng hợp dự án "Cập nhật kế hoạch hành động ứng phó BĐKH tỉnh Vĩnh Long”.

[21]. Ban chỉ huy PCTT\&TKCN tỉnh Vĩnh Long, 2015. Báo cáo kết quả phòng chống thiên tai và tìm kiếm cứu nạn tỉnh Vĩnh Long 2015.

[22]. Bộ Kế hoạch và Đầu tư, 2015. Ngân sách cho ứng phó Biến đổi khí hậu tại Việt Nam: Đầu tư thông minh vì tương lai bền vững.

[23]. Bộ Tài nguyên và Môi trường, 2014. Chương trình hỗ trợ ứng phó với $\mathrm{BĐKH} \mathrm{(SP-RCC)} \mathrm{ở}$ Việt Nam. 